\title{
Action of the Disintegrin Contortrostatin on Breast Cancer Cell Primary Cultures
}

\author{
Ifigeneia Marinou ${ }^{1}$, Sophia Havaki ${ }^{1}$, Nikos Goutas ${ }^{2}$, Dimitrios Vlachodimitropoulos ${ }^{2}$, \\ Georgios Baltatzis ${ }^{3}$, Eumorphia G. Konstantakou ${ }^{4}$, Dimitrios J. Stravopodis ${ }^{4}$, \\ Dimitrios G. Koudoumas ${ }^{5}$, Evangelos Marinos ${ }^{1}$, Mirsini Kouloukoussa ${ }^{1}$ \\ ${ }^{1}$ Laboratory of Histology and Embryology, Medical School, University of Athens, Athens, Greece \\ ${ }^{2}$ Laboratory of Forensic Medicine and Toxicology, Medical School, University of Athens, Athens, Greece \\ ${ }^{3}$ 1st Department of Pathology, Medical School, University of Athens, Athens, Greece \\ ${ }^{4}$ Department of Cell Biology and Biophysics, Faculty of Biology, University of Athens, Athens, Greece \\ ${ }^{5}$ Laboratory of Experimental Surgery and Surgical Research, University of Athens, Athens, Greece \\ Email: emarinos@med.uoa.gr
}

Received July 8, 2013; revised August 7, 2013; accepted August 15, 2013

Copyright (C) 2013 Ifigeneia Marinou et al. This is an open access article distributed under the Creative Commons Attribution License, which permits unrestricted use, distribution, and reproduction in any medium, provided the original work is properly cited.

\begin{abstract}
Integrins mediate cell adhesion to the extracellular matrix (ECM). In particular, integrin alphavbeta3 recognizes the RGD motif as a ligand-binding site on various extracellular molecules of the extracellular matrix. Integrin aphavbeta3 has been associated with high malignant potential in breast cancer cells, and has signalized the onset of widespread metastasis. In recent years, several antagonists of integrin alphavbeta3, including snake venom disintegrins, have been used as potential anti-cancer agents. In the present work, the effect of contortrostatin, a disintegrin isolated from the venom of the snake Agkistrodon contortrix, was studied on primary cultures of human breast cancer cell. Scanning and transmission electron microscopy were employed in order to examine alterations in cell morphology and fluorescent microscopy and visualize changes in distribution of integrin alphavbeta3 and talin. Fluorescent localization of caspase 8 was made in order to visualize any sign of proapoptotosis and western immunoblotting of integrin, talin and annexin was undertaken in order to identify changes. The results suggest that the snake venom contortrostatin seriously affects cell morphology, adhesion and mobility and induces breast cancer cells to apoptosis.
\end{abstract}

Keywords: Breast Cancer; Disintegrins; Contortrostatin; Integrin Alphavbeta3; Apoptosis; Primary Cultures

\section{Introduction}

Breast cancer affects one in ten women in developed nations. The prognosis is favorable for women with clinically confined tumors at the time of diagnosis, but mortality rates are greater than $80 \%$ in cases in which the tumor has metastasized to distant sites [1]. Many of the carcinogenesis progression steps involve integrins. Integrins are dimeric adhesion receptors that mediate cellular attachment to the extracellular matrix (ECM) or to adjacent cells. All integrins are $\alpha / \beta$ heterodimers and various pairings of $\alpha$ and $\beta$ subunits confer to specificity toward distinct ECM proteins. Different $\alpha$ subunits may combine with the same $\beta$ subunit, and conversely, different $\beta$ chains are capable of pairing with a particular $\alpha$ subunit $[2,3]$. Their heterodimeric composition generally confers to ligand specificity, according to which they are classified in four classes, which are those that recognize collagen, laminin, the tripeptide sequence Arg-Gly-Asp
(RGD), and several specific leukocyte associated ligands [4]. The interaction of the ECM with integrins on the cell surface leads to integrin association with cytoskeletal elements, resulting in the formation of specialized adhesive junctions, such as focal adhesions [5]. Formation of focal adhesions triggers a series of intracellular signaling essential for cell adhesion, spreading, migration, proliferation, survival and differentiation [6,7]. Several observations indicate that the changes in the integrin activation state and the alteration in the level of expression of integrins or their ECM ligands contribute to neoplastic progression [8,9]. For example, the level of expression of integrin alphavbeta3 $\left(\alpha_{v} \beta_{3}\right)$-a vitronectin receptor-that binds to extracellular matrix molecules, via an RGD-binding site [10], in melanoma and other cancers is proportional to the invasiveness of the tumors [11]. In breast cancer cells, high expression of activated alphavbeta3 - but not that of non-activated alphavbeta3 - is 
associated with a highly aggressive metastatic phenotype, and signalizes the onset of widespread metastasis [12]. Since the RGD sequence is an important cell attachment recognition site for several classes of integrins in many ECM proteins, agents that disrupt interactions of these integrins should have significant anti-tumor activity. Among these are small molecule compounds [13], peptidomimetics [14], disintegrins [15] and monoclonal antibodies [16].

Disintegrins are a family of polypeptides found in the venom of viper snakes. Contortrostatin $(\mathrm{CN})$ is a 13.5 $\mathrm{kDa}$ dimeric disintegrin isolated from the venom of the Southern Copperhead snake, Agkistrodon contortrix contortrix. Each of the monomeric chains contains 65 amino acids and possesses an Arg-Gly-Asp (RGD) motif at the tip of a flexible loop stabilized by disulfide bonds $[17,18]$. Interaction of $\mathrm{CN}$ with tumor cells is primarily modulated by the RGD motif [19]. Investigations have shown that consequently, disintegrins and $\mathrm{CN}$ are potent functional blockers of multiple integrins including $\alpha_{v} \beta_{3}$ [19] and that CN blocks breast cancer cell adhesion and migration [20,21]. In addition, it inhibits tumor-induced angiogenesis by blocking important angiogenic pathways in endothelial cells mediated by integrins $\alpha_{5} \beta_{1}, \alpha_{v} \beta_{3}$ and $\alpha_{v} \beta_{5}$ [22,23]. These diverse mechanisms of action provide $\mathrm{CN}$ with a distinct advantage over many other antitumor and anti-angiogenic agents, which only block a single angiogenic pathway and do not directly affect the growth of tumor cells [24].

Past studies have shown $\mathrm{CN}$ to be an effective agent in limiting tumor growth and spread. The present report extends and enhances these studies by describing for the first time the effects of $\mathrm{CN}$ on cell motility and adhesion in a model system consisting of primary cultures of breast cancer cell established from breast cancer tissue fragments. As an effective broad-spectrum anti-invasive drug, $\mathrm{CN}$ may hold an advantage over other anti-tumor therapeutic modalities in that it may be better suited to address breast cancer cell survival.

\section{Materials and Methods}

\subsection{Clinical Material}

The material of this study was obtained from Evgenidion University Hospital and consisted of 85 cases of infiltrating ductal breast carcinomas, surgically removed from female patients. Informed consent was obtained for all medical procedures performed during the course of the patient's illness. All investigational biopsies were approved by the Athens Medical School Ethics Committee No. 5758/12-3-03). Cell culturing and further processing of the tissue were carried out at the Laboratory of Histology and Embryology, Athens Medical School.

\subsection{Primary Cell Cultures}

Sterilized plastic Petri dishes $35 \mathrm{~mm}$ in diameter and round glass cover slips ( $\phi 13 \mathrm{~mm})$ were pre-coated with human plasma vitronectin (G538A, Promega) $(0.2$ $\left.\mu \mathrm{g} / \mathrm{cm}^{2}\right)$ in DPBS (14040, Gibco) overnight at room temperature. The coating solution was then replaced with 2 $\mathrm{mg} / \mathrm{ml} \mathrm{BSA} \mathrm{(11930,} \mathrm{Serva)} \mathrm{in} \mathrm{DPBS} \mathrm{for} 2 \mathrm{~h}$ at $37^{\circ} \mathrm{C}$ to block non-specific binding sites. From each biopsy, several small $\left(2-3 \mathrm{~mm}^{3}\right)$ tissue fragments were placed either on the coverslips in a Petri dish or directly on the Petri dishes. The cells were grown in RPMI 1640 supplemented with 10\% Fetal Calf Serum (FCS), $1 \mathrm{mM}$ L-glutamine, $1 \%$ penicillin and $1 \%$ streptomycin, at $37^{\circ} \mathrm{C}$, under $5 \% \mathrm{CO}_{2}$ and were allowed to migrate out of the tissue fragment using the explant technique, without any mechanical or enzymatic tissue disaggregation. The cell growth was complete in about 2 - 3 weeks.

\subsection{CN Incubation}

When the cells were fully grown, they were incubated with venom from Agkistrodon contortrix mokason purchased from Sigma-Aldrich (V4125) at a concentration of $10 \mu \mathrm{g} / \mathrm{ml}$. The cultures without the addition of the venom were used as negative control. All incubations were performed at $37^{\circ} \mathrm{C}$ for $2 \mathrm{~h}$ in serum-free culture medium in order to avoid the effect of serum proteins.

\subsection{Scanning (SEM) and Transmission Electron Microscopy (TEM)}

For SEM preparation, tissue fragments and cells-attached on the glass coverslips coated with vitronectinwere rinsed with $0.05 \mathrm{M}$ cacodylate-Na buffer solution and fixed in $2.5 \%$ glutaraldehyde in $0.05 \mathrm{M}$ cacody-

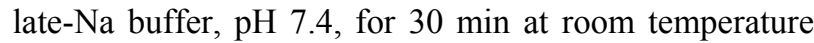
(RT). Coverslips were then dehydrated with increasing concentrations of ethanol (for $3 \mathrm{~min}$ each in 25\%,50\%, $70 \%, 95 \%$ ethanol and for $5 \mathrm{~min}$ in $100 \%$ ethanol twice). The specimens were then infiltrated gradually in a mixture of amyl-acetate diluted in $100 \%$ ethanol $(1: 2,1: 1$, 2:1), 5 min each at RT and finally in 100\% amyl-acetate 3 times for $5 \mathrm{~min}$. The specimens were then covered with one drop of hexamethyldisilazane and were dried overnight. Before the observation, they were rendered conductive by sputtering them with gold before being observed by a JEOL JSM 4500 scanning electron microscope operated at $3 \mathrm{kV}$. For TEM preparation, breast cancer cell monolayers were grown on vitronectin-coated dishes. They were then fixed in $2.5 \%$ glutaraldehyde

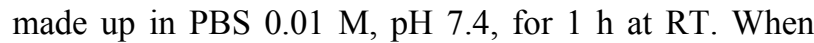
required, cells were treated with contortrostatin for $2 \mathrm{hrs}$. Cells were collected according to Georgoulis et al. [25]. Semithin sections ( $1 \mu \mathrm{m}$ thickness) were cut on a Leica Ultracut $\mathrm{R}$ ultramicrotome with glass knives and stained 
with $1 \%$ toluidine blue. Ultrathin 60 to $80 \mathrm{~nm}$ sections were cut with a Diatome diamond knife, and mounted onto 200-mesh. The thin sections were counterstained with saturated ethanolic uranyl acetate and lead citrate and were viewed in a Zeiss EM 900 electron microscope, at $80 \mathrm{kV}$ accelerating voltage, with an objective aperture of $30 \mu \mathrm{m}$. Digitized images were saved as high resolution TIFF files and printed — when required — at 1000 dpi on a HP Laserjet $4250 \mathrm{n}$ high resolution laser printer.

\subsection{Double Immunofluorecence of Integrin Alphavbeta3, Annexin V, Caspase 8 and Talin}

For immunolocalization experiments, cells were grown on glass coverslips coated with vitronectin and were treated with contortrostatin mokason as described above. The cells were fixed in 3\% paraformaldehyde in phos-

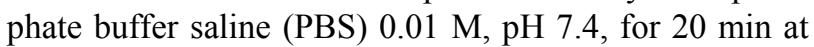
RT washed with PBS and incubated with both primary antibodies: a. monoclonal mouse anti-human integrin alphavbeta3 antibody LM609 (60 $\mu \mathrm{g} / \mathrm{ml})$ (MAB1976, Chemicon) diluted in PBS, pH 7.4, containing 5\% normal goat serum (NGS) and 3\% bovine serum albumin, BSA (A7638, Sigma), and b. caspase 8 rabbit polyclonal antibody $(200 \mu \mathrm{g} / \mathrm{ml})$ (sc-7890, Santa Cruz Biotechnology) diluted 1:200 in PBS, pH 7.4, containing 5\% normal goat serum (NGS) (X0907, Dako) and 3\% bovine serum albumin, BSA (A7638, Sigma). Incubations were performed overnight at $4^{\circ} \mathrm{C}$. In order to detect whether the cells had been induced to enter apoptosis they were further double incubated with two antibodies: a. monoclonal mouse anti-human annexin $\mathrm{V}$ antibody (VAA-33): sc-65391, (Santa Cruz Biotechnology) diluted 1:400 and b. caspase 8 rabbit polyclonal antibody $(200 \mu \mathrm{g} / \mathrm{ml})$ (sc-7890, Santa Cruz Biotechnology) diluted 1:200 in $\mathrm{PBS}, \mathrm{pH} 7.4$, containing 5\% normal goat serum (NGS) (X0907, Dako) and 3\% bovine serum albumin, BSA (A7638, Sigma). A third double incubation was performed with: a. monoclonal mouse anti-human talin antibody (sc-5988, Santa Cruz Biotechnology), diluted $1: 300$ and b. caspase 8 rabbit polyclonal antibody (200 $\mu \mathrm{g} / \mathrm{ml}$ ) (sc-7890, Santa Cruz Biotechnology) diluted 1:200 in PBS, pH 7.4, containing 5\% normal goat serum (NGS) (X0907, Dako) and 3\% bovine serum albumin, BSA (A7638, Sigma). All incubations were performed overnight at $4^{\circ} \mathrm{C}$. The cells for all cases were subsequently incubated with the secondary goat anti-mouse IgG Alexa 488-conjugated antibody (1:100) (A11001, Invitrogen) diluted in $\mathrm{PBS}, \mathrm{pH} 7.4$, containing $1 \%$ bovine serum albumin (BSA) (A7638, Sigma), and the goat anti-rabbit 555 Biotium $(3 \mu \mathrm{g} / \mathrm{ml})$ diluted in $2 \%$ Triton $\mathrm{X}$ and $3 \%$ bovine serum albumin (BSA) (A7638, Sigma) in PBS $0.001 \mathrm{M}$ for $1 \mathrm{~h}$ at RT.

\subsection{Western Immunoblotting of Beta3 Integrin Subunit, Annexin V and Talin}

$2 \mathrm{~h}$ after treatment with $10 \mu \mathrm{g} \mathrm{CN}$ mokason, breast cancer cells were harvested, washed twice with PBS, solubilized in sample buffer (125 mM Tris-Hcl pH 6.8, 5\% beta-mercaptoethanol, $6 \%$ SDS, $10 \%$ glycerol, $1 \mathrm{mM}$ PMSF and bromophenol blue) for $2 \mathrm{~min}$ at $100^{\circ} \mathrm{C}$ and sonicated for $2 \times 15 \mathrm{sec}$ each. After centrifugation at $12000 \mathrm{~g}$ for $20 \mathrm{~min}$ at $25^{\circ} \mathrm{C}$, the supernatant was collected as total protein extract and stored at $-30^{\circ} \mathrm{C}$. Protein concentrations were measured using the Bradford-type protein assay (Bio-Rad, USA). Equal amounts of protein $(40 \mu \mathrm{g})$ were separated by SDS-polyacrylamide gel electrophoresis and electrotransferred to nitrocellulose membrane (BA85 Protran, Whatman, UK). Each membrane was blocked with 5\% non-fat dry milk (or 5\% BSA where required) in TBS-T [20 mM Tris- $\mathrm{HCl}$ ( $\mathrm{pH} 7.6), 137 \mathrm{mM} \mathrm{NaCl}$ and $0.2 \%$ Tween-20] for $2 \mathrm{~h}$ at room temperature and subsequently incubated with rabbit anti-human integrin beta3 primary antibody (1:1000) (AB1932, Chemicon), with mouse anti-human Annexin V(VAA-33) primary antibody (1:1000) (sc-65391,Santa Cruz Biotechnology), and a mouse anti-chicken Talin primary antibody (1:1000) (sc-59881, Santa Cruz Biotechnology) for $16 \mathrm{~h}$ at $4^{\circ} \mathrm{C}$. Immunoreactivity was detected by sequential incubation with HRP-conjugated secondary antibody (1:2000) [anti-rabbit (\#A4914, Sigma-Aldrich) or anti-mouse (\#M6898, Sigma-Aldrich)] and ECL reagents (Amersham, GE Healthcare, UK). Data were obtained from three different experiments, one of which is illustrated in the present study. The antibodies recognizing Pan-Actin (\#4968) were obtained from Cell Signalling Technology Inc. (Hertfordshire, UK).

\section{Results}

\subsection{Scanning and Transmission Electron Microscopy}

Under the SEM, the morphology of breast cancer cells was studied in primary cultures after treatment with contortrostatin mokason venom. Untreated cultures were used as controls, where cancer cells spread out from the tissue biopsy presenting a normal flattened appearance with polygonal astrocytic shape and well-developed membrane projections (Figure 1). On the contrary, the venom treatment resulted in a generally altered morphological appearance of the cancer cells: Most of the cells became shrunk with irregular cytoplasmic protrusions and the general appearance of the monolayer was distorded (Figure 2). A few cells detached from the substrate. In higher magnification, it was clear that affected cancer cells became rounded with the central part of their cell body tending to become partially detached from the substrate, whereas their filopodia and lamellipodia still 


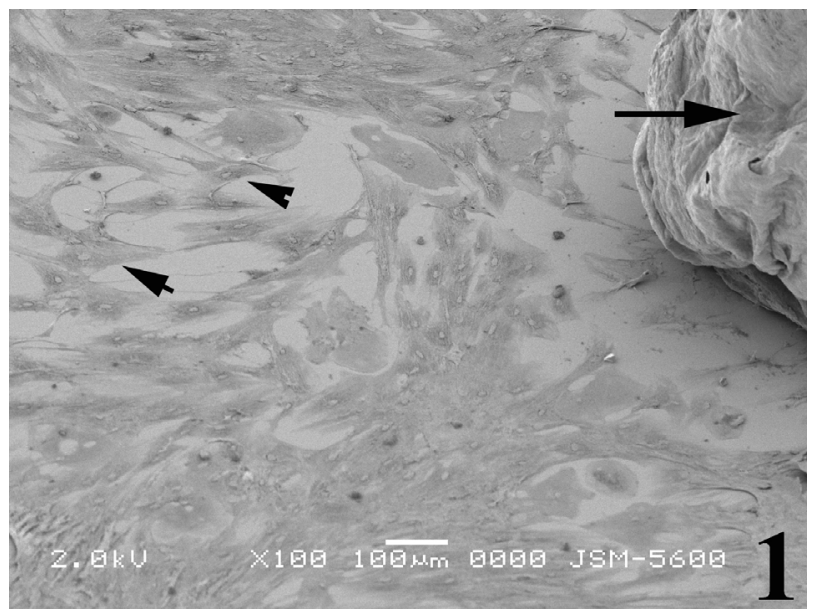

Figure 1. Scanning electron micrograph illustrating breast cancer cells spreading out of a biopsy tissue sample (arrow) in primary culture. The cells possess a typical epithelial phenotype with flat polygonal shape (arrowheads).

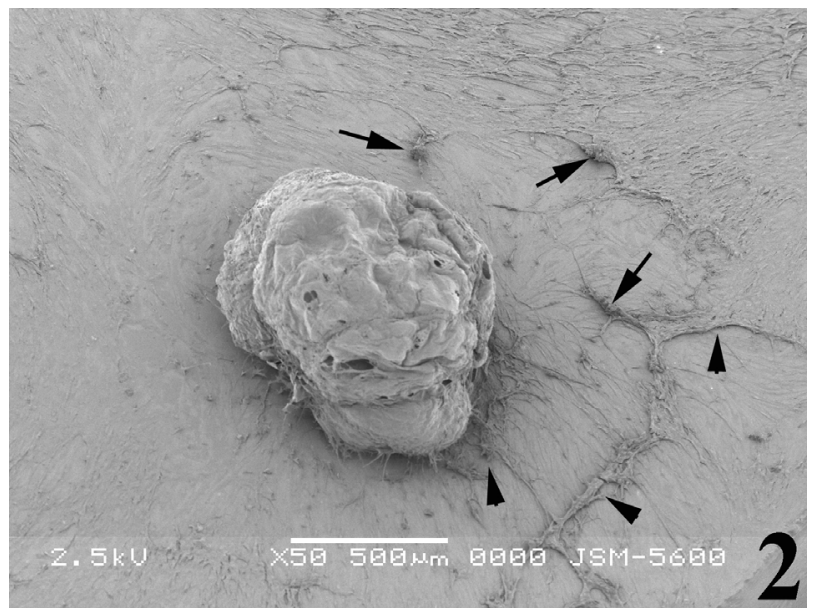

Figure 2. Scanning electron micrograph illustrating breast cancer cells incubated with the snake venom contortrostatin. Cells become rounded and shrinked (arrows) and most of them tend to detach from the substrate (arrowheads).

remained firmly attached to the substrate (Figure 3). Very few cells became almost rounded assembling into aggregates, while a quite low proportion of cells were resistant to the venom effect and exhibited not apparent morphological alterations.

Under the transmission electron microscope, control (untreated) cells had a regular cytoplasm and exhibited a dense network of actin microfilaments near the cell attachment sites, as well as noumerous actin bundles (Figure 4). In contrast, major characteristics of the venomtreated cancer cells were the absence of actin bundles near cell attachment sites, the distorted appearance of mitochondria that showed irregular cristae and their low density matrix, as well the extensive cytoplasmic vacuolation (Figure 5).

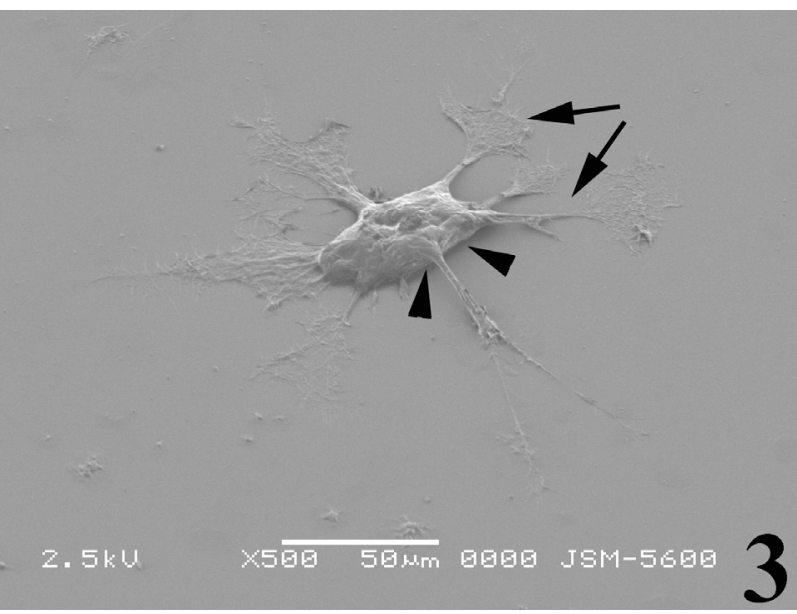

Figure 3. Scanning electron micrograph illustrating a breast cancer cell from a culture incubated with the snake venom contortrostatin. The cell body tends to become rounded and irregular cytoplasmic extensions are formed (arrows). Cell detachment from the substrate is evident at places (arrowheads).

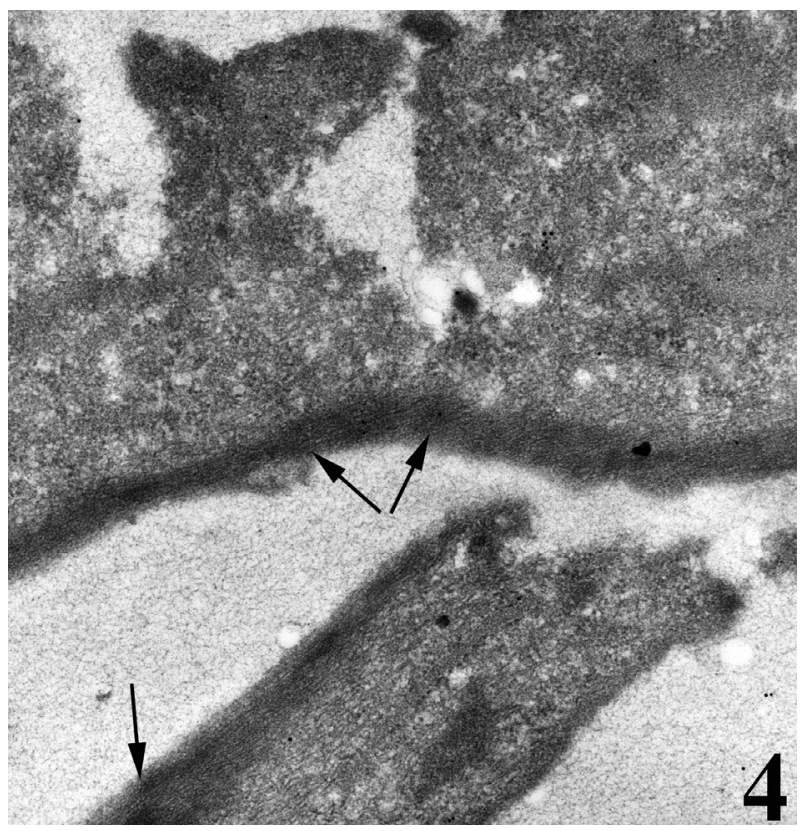

Figure 4. Transmission electron micrograph of a breast cancer cell in vitro under normal culturing condtitions. The cell is well attached onto the substrate with plenty of actin microfilaments forming bundles (arrows).

\subsection{Double Immunofluorecence of Alphavbeta3, Annexin V, Caspase 8 and Talin}

The distribution of integrin alphavbeta3, annexin V, caspase 8 and talin in breast cancer cells biopsies was analyzed by double immunofluorescent microscopy (Figures 6(a)-(I)). Control (untreated) cells are negative for both caspase 8 (Figures 6(a), (e) and (i)) and annexin V (Figure 6(c)). In contrast, cancer cells incubated with the 


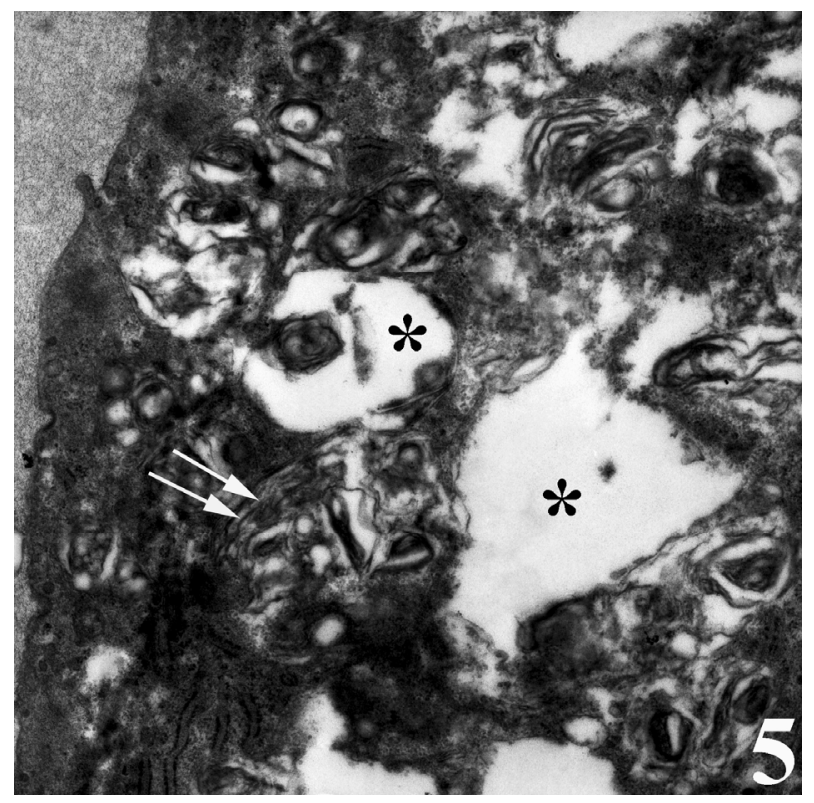

Figure 5. Transmission electron micrograph of a breast cancer cell in vitro incubated with the snake venom contortrostatin. Actin microfilaments forming bundles are not visible near dorsal cell membrane. Signs of early apoptosis are observed, such as cytoplasmic vacuolation (*) and irregular mitochondrial structure in the form of distorted cristae (double arrows) and low density matrix.

venom indicate intense cytoplasmic staining for annexin V (Figure 6(d)) and caspase 8 (Figure 6(b), (f) and (j)). Breast cancer cells were also double immunostained for caspase $8 / \alpha_{v} \beta_{3}$. The integrin $\alpha_{v} \beta_{3}$ in control cancer cells are observed as punctuate characteristic bright aggregations evenly distributed all over the cell surface (Figure 6(g)). After venom treatment the pattern of integrin appeared altered. The integrin is accumulated at the periphery of the cancer cells, forming thin fingerlike integrin clusters (Figure 6(h)). Finally, double immunostaining for caspase 8/talin (Figures 6(i)-(I)) indicates that talin at untreated cancer cells shows a very faint and diffuse pattern of fluorescence localization (Figure 6(k)). After treatment of cancer cells with the venom, talin exhibits a characteristic pattern of distribution and localizes at the periphery of cells forming clusters distributed irregularly (Figure 6(I)). Caspase 8 has the same localization pattern, in both control and venom-treated cells (Figure 6(a), (b), (e), (f), (i) and (j)).

\subsection{Western Immunoblotting for Integrin Beta3 Subunit, Annexin V and Talin}

To determine whether the contortrostatin mokason caused - apart from redistribution - changes in integrin alphavbeta3 expression, Western immunoblot analysis of integrin beta3 subunit was applied in order to quantitatively assess the expression of integrin alphavbeta 3 in breast cancer cells treated with the venom. In addition to this, the expression of annexin $\mathrm{V}$ in breast cancer cells was also examined, in order to verify the entry of cancer cells to apoptosis after their exposure to mokason. Furthermore talin, which is responsible for mediating the interaction between actin cytoskeleton and integrins, was also assessed, since it is known that shows significantly increased expression in cancer cells and this overexpression correlates with progression to metastatic disease. In parallel, the level of actin expression was examined in the same samples, as an internal control, in order to verify equal loading of the gel. Equal amounts of total protein were subjected to immunoblot analysis with anti-beta3, anti-annexin V, anti-talin and anti-actin antibodies. As shown in Figure 7, the levels of beta3 subunit in breast cancer cells treated with the venom demonstrated a similar expression pattern compared to levels in untreated cells (Figure 7(c)). Annexin V is detected only in breast cancer cells treated with mokason and not in untreated cells, which indicates that cancer cells enter pre-apoptosis after the mokason treatment (Figure 7(b)). Talin, shows overexpression in treated with mokason breast cancer cells compared to untreated cells (Figure $7(d))$.

\section{Discussion}

In the present work, the effects of disintegrin contortrostatin isolated from A. contortrix mokason venom were studied on well-spread human breast cancer cells from primary cultures, using the explant technique. More specifically, an effort was made to study the anti-tumorigenic effects of this disintegrin on the adhesion and motility of these cells through the expression of integrin alphavbeta 3 and the subsequent entry to apoptotic pathways, therefore affecting the metastatic potential of the cancer cells. The results showed that incubation of primary cultures of breast cancer cell monolayers with contortrostatin causes a major morphological perturbation of the cell cytoskeleton as well as induction to apoptosis.

Disintegrins have been used in a number of cases in order to clarify their role in a variety of normal and pathological tissues. Snake venoms and hemostatic system have been under consideration in relation to the role of disintegrins in platelet aggregation [26]. The anti-invasive activity of contortrostatin has been studied using human glioblastoma cell lines [27] as well as its anti-tumor activity in Ehrich ascites carcinoma [28].

The critical involvement of integrins in both angiogenesis [29,30] and tumor invasion [31] provides the rationale for developing therapeutic antagonists aimed at disrupting these molecularly intertwined and derailed processes [32]. Most efforts of the past were focused on anti-integrin agents targeting the RGD-binding alphav members, and a subclass of integrins was thought to play pivotal roles in the regulation of pathological angiogenesis, 

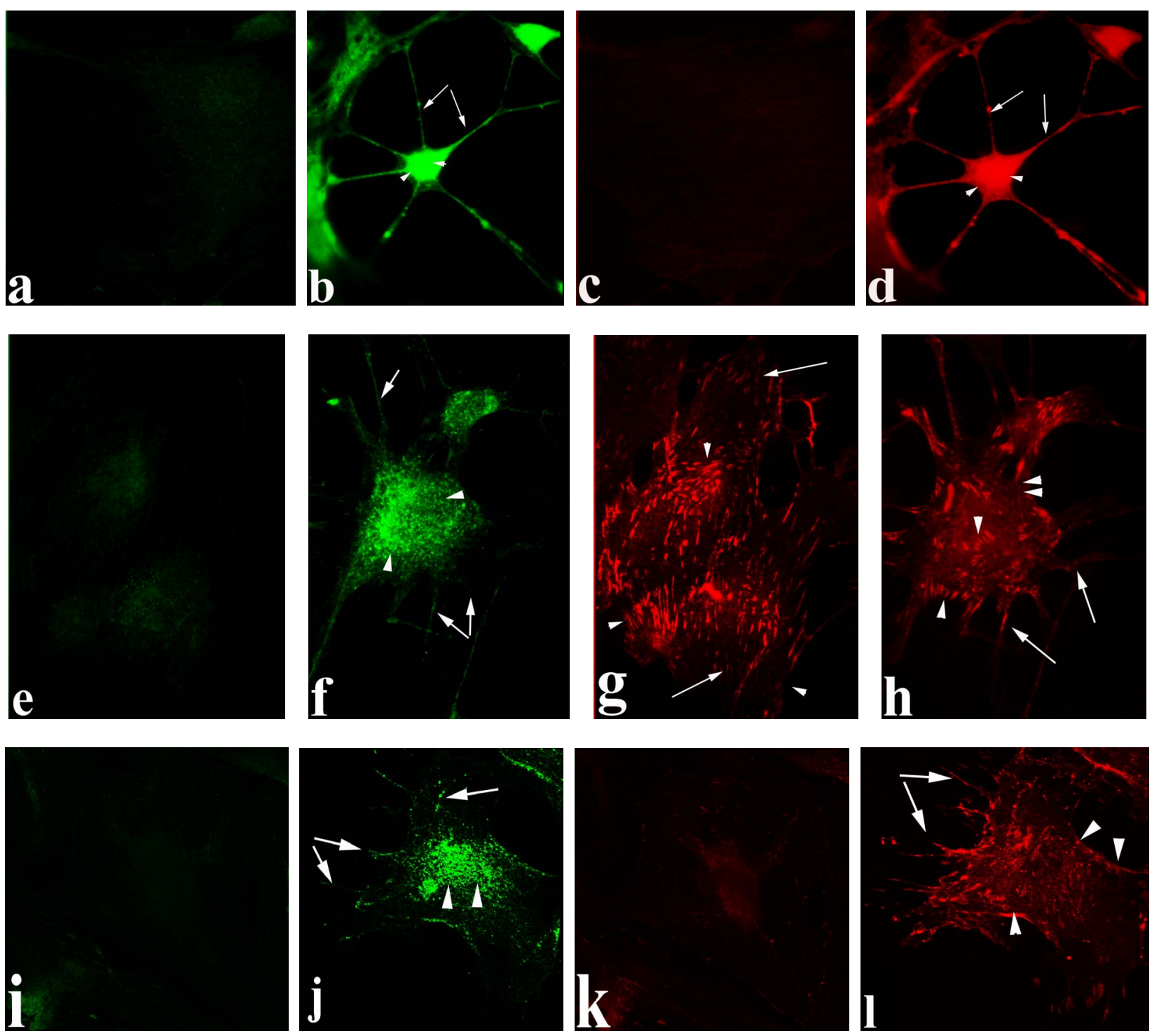

Figure 6. Control and venom-incubated breast cancer cells with double immunofluorescent staining. (a)-(d): caspase 8/annexin $V$ double immunostaining: (a) caspase 8 activity is negative in controls, (b) caspase 8 activity is prominent in venom-treated cells and is diffuse throughout cell body, (c) annexin $\mathrm{V}$ activity is negative in controls, (d) annexin $\mathrm{V}$ activity is prominent and localized throughout cell body; (e)-(h): caspase 8/ $\alpha_{v} \beta_{3}$ double immunostaining: (e) caspase 8 activity in controls is negative, (f) caspase 8 activity in venom-treated cells is diffuse throughout cell body and around nucleus, (g) integrin $\alpha_{v} \beta_{3}$ localization in control cells, (h) integrin $\alpha_{v} \beta_{3}$ localization is perturbated in venom-treated cells, exhibiting irregular clustering along cell membrane; (i)-(l): caspase 8/talin double immunostaining: (i) caspase 8 is negative in controls, (j) caspase 8 produces a diffuse pattern of localization in venom-treated cells, $(k)$ talin in controls shows a very faint and diffuse pattern of fluorescence localization, (l) talin staining is prominent in venom-treated cells, giving a diffuse staining pattern in cell body and dotted distribution along cell periphery.

which prompted the development of a number of small RGD-mimetics and monoclonal antibodies [33,34]. The therapeutic modulation of multiple integrin pathways via soluble disintegrins was previously shown by several workers to elicit potent anti-angiogenic and anti-metastatic effects in several animal cancer models [35]. Although the clinical relevance of the preclinical studies so far is not clear [36], the available data support the idea that there is an imperative need not only to design novel anti-angiogenic drugs with better anti-invasive properties, but also to test the impact of standard of care anti-angiogenics on metastasis and/or postoperative survival when they are administered in combination with anti-invasive modalities. In this context, primary breast cancer cell cultures have been proved to be quite reliable in cell attachment and mobility studies which directly relate to the metastatic potential of the tumor cells. Primary cultures retain their original cell phenotype and 


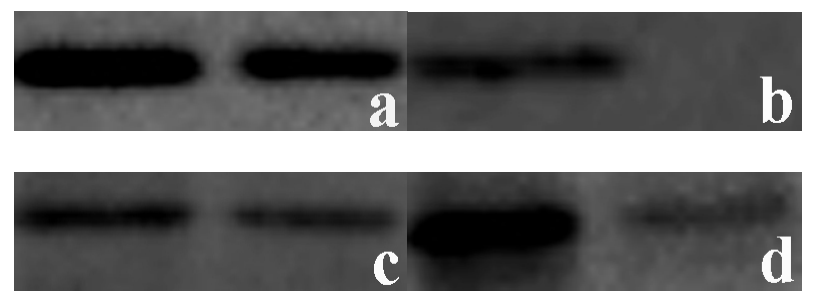

Figure 7. Western immunoblot analysis of (a) actin, (b) annexin $V$, (c) integrin subunit $b 3$ and (d) talin from primary cultures of breast cancer cells incubated with contortrostatin. In each pair, lanes on the right correspond to untreated (control) cells, lanes on the left correspond to venom-treated cells.

offer flexibility as compared to the animal models. To the best of our knowledge, it is the first time that a primary culture model system is used in order to examine the anti-tumorigenic and anti-invasive properties of contortrostatin in breast cancer. Studies employing cell lines have shown that contortrostatin can be effectively used in vitro in a number of cases [37], but there is no information about the effect of this drug in a primary culture of breast cancer cell where tumor cells retain their original phenotype. The results in our study are in agreement with data provided by other workers $[27,35]$ and they extend our previous observations $[25,38]$ on the use of RGD peptides in primary breast cancer cultures.

Drug assays, in general, may be qualitative or quantitative. In the context of clinical envenoming, a quantitative assay is only useful if the degree of pathological damage in vivo can be correlated with an amount of the causative substance detected in vitro. There should be a linear correlation between dose and effect (a clear physiological end point) which may be measured easily. This may not be possible where synergy, inhibition and host responses interfere with activity of venom constituents (i.e. disintegrins) in vivo. Qualitative or functional in vitro assays are therefore probably the most useful, but they also have limitations. They may depend on the assumption that the animal or pharmacological substrates used in the test have human counterparts and extrapolation from in vitro results to the in vivo clinical situation may be perilous. The most acceptable in vitro assays, both scientifically and ethically are those in which human tissue is used [39]. From this point of view, primary cultures from tissue biopsies appear to be the best choice for disintegrin testing.

In summary, we developed a primary culture model system in order to study the anti-migration properties of contortsostatin in breast cancer. Contortrostatin had been proved that it not only potently altered cytoskeleton dynamics, but also had a profound apoptotic effect when tested on breast cancer cells. The results could be used to further improve strategies in preclinical studies.

\section{Acknowledgements}

Credits are given to Digital Image Systems Company, Athens, Greece for technical support with the confocal microscope and immunofluorescent techniques and photography. This research has been co-financed by the European Union (European Social Fund-ESF) and Greek National Funds through the Operational Program "Education and Lifelong Learning" of the National Strategic Reference Framework (NSRF) - Research Funding Program: Heraclitus II. Investing in knowledge society through the European Social Fund (grand: 70/3/11017).

\section{REFERENCES}

[1] R. E. Coleman, P. Smith and R. D. Rubens, "Clinical Course and Prognostic Factors Following Bone Recurrence from Breast Cancer," British Journal of Cancer, Vol. 77, No. 2, 1998, pp. 336-340. http://dx.doi.org/10.1038/bjc.1998.52

[2] R. O. Hynes, "Integrins: Versatility, Modulation, and Signaling in Cell Adhesion," Cell, Vol. 69, No. 1, 1992, pp. 11-25.

http://dx.doi.org/10.1016/0092-8674(92)90115-S

[3] A. Cheresh, "Structural and Biologic Properties of Integrin Mediated Cell Adhesion," Clinical Laboratory Medicine, Vol. 12, No. 2, 1992, pp. 217-236.

[4] A. L. Berrier and K. M. Yamada, "Cell-Matrix Adhesion," Journal of Cell Physiology, Vol. 213, No. 3, 2007, pp. 565-573. http://dx.doi.org/10.1002/jcp. 21237

[5] F. G. Giancotti and F. Mainiero, "Integrin-Mediated Adhesion and Signaling in Tumorgenesis," Biochimica Biophysica Acta, Vol. 1198, No. 1, 1994, pp. 47-64. http://dx.doi.org/10.1016/0304-419X(94)90005-1

[6] P. Jiang, A. Enomoto and M. Takahashi, "Cell Biology of the Movement of Breast Cancer Cells: Intracellular Signaling and the Actin Cytoskeleton," Cancer Letters, Vol. 284, No. 2, 2009, pp. 122-130.

http://dx.doi.org/10.1016/j.canlet.2009.02.034

[7] C. Brakebusch, D. Bouvard, F. Stanchi, T. Sakai and R. Fassler, "Integrins in Invasive Growth," Journal of Clinical Investigation, Vol. 109, No. 8, 2002, pp. 9991006. http://dx.doi.org/10.1172/JCI0215468

[8] R. E. Hewitt, D. G. Powe, K. Morrell, E. Balley, I. H. Leach, I. O. Ellis and D. R. Turner, "Laminin and Collagen IV Subunit Distribution in Normal and Neoplastic Tissues of Colorectum and Breast," British Journal of Cancer, Vol. 75, No. 2, 1997, pp. 221-229. http://dx.doi.org/10.1038/bjc.1997.37

[9] M. Rolli, E. Fransvea, J. Pilch, A. Saven and B. FeldingHabermann, "Activated Integrin Alphavbeta3 Cooperates with Metalloproteinase MMP-9 in Regulating Migration of Metastatic Breast Cancer Cells," Proceedings National Academy of Sciences of the USA, Vol. 100, No. 16, 2003, pp. 9482-9487. http://dx.doi.org/10.1073/pnas.1633689100

[10] E. F. Plow, T. A. Haas, L. Zhang, J. Loftus and J. W. Smith, "Ligand Binding to Integrins," Journal of Bio- 
logical Chemistry, Vol. 275, No. 29, 2000, pp. 2178521788.

http://dx.doi.org/10.1074/jbc.R000003200

[11] K. Jacob, A. K. Bosserhoff, F. Wach, R. Knuchel, E. C. Klein, R. Hein and R. Buettner, "Characterization of Selected Strongly and Weakly Invasive Sublines of a Primary Human Melanoma Cell Line and Isolation of Subtractive cDNA Clones," International Journal of Cancer, Vol. 60, No. 5, 1995, pp. 668-675. http://dx.doi.org/10.1002/ijc.2910600517

[12] E. Kawahara, K. Imai, S. Kumagai, E. Yamamoto and I. Nakanishi, "Inhibitory Effects of Adhesion Oligopeptides on the Invasion of Squamous Carcinoma Cells with Special Rreference to Implication of av Integrins," Journal of Cancer Research and Clinical Oncology, Vol. 121, No. 3, 1995, pp. 133-140. http://dx.doi.org/10.1007/BF01198094

[13] N. Reinmuth, W. Liu, S. A. Ahmad, F. Fun, O. Stoeltzing, A. A. Parikh, C. D. Bucana, G. E. Gallick, M. A. Nickols, W. F. Westlin and L. M. Ellis, "Alphavbeta3 Integrin Antagonist S247 Decreases Colon Cancer Metastasis and Angiogenesis and Improves Survival in Mice," Cancer Research, Vol. 63, No. 9, 2003, pp. 2079-2087. http://cancerres.aacrjournals.org/content/63/9/2079

[14] D. G. Batt, J. J. Petraitis, G. C. Houghton, D. P. Modi, G. A. Cain, M. H. Corjay, S. A. Mousa, P. J. Bouchard, M. S. Forsythe, P.P. Harlow, F. A. Barbera, S. M. Spitz, R. R. Wexler and P. K. Jadhav, "Disubstituted Indazoles as Potent Antagonists of the Integrin Alpha(v)beta(3)," Journal of Medical Chemistry, Vol. 43, No. 1, 2000, pp. 41-58. http://dx.doi.org/10.1021/jm990049j

[15] C. Barja-Fidalgo, A. L. Coelho, R. Saldanha-Gama, E. Helal-Neto, A. Mariano-Oliveira and M. S. Freitas, "Disintegrins: Integrin Selective Ligands Which Activate Integrin-Coupled Signaling and Modulate Leukocyte Functions," Brazilian Journal of Medical and Biological Research, Vol. 38, No. 10, 2005, pp. 1513-1520. http://dx.doi.org/10.1590/S0100-879X2005001000008

[16] D. Zhang, T. Pier, D. G. McNeel, G. Wilding and A. Friedl, "Effects of a Monoclonal Anti-Alphavbeta3 Integrin Antibody on Blood Vessels-A Pharmacodynamic Study," Investigations of New Drugs, Vol. 25, No. 1, 2007, pp. 49-55.

http://dx.doi.org/10.1007/s10637-006-9013-8

[17] N. Moiseeva, S. D. Swenson, F. S. Markland Jr. and R. Bau, "Purification, Crystallization and Preliminary X-Ray Analysis of the Disintegrin Contortrostatin from Agkistrodon contortrix contortrix Snake Venom," Acta Crystallographica D: Biological Crystallography, Vol. 58, No. 17, 2002, pp. 2122-2124. http://dx.doi.org/10.1107/S0907444902011204

[18] M. A. McLane, S. Vijay-Kumar, C Marcinkiewicz, J. J. Calvete and S. Niewiarowski, "Importance of the Structure of the RGD-containing Loop in the Disintegrins Echistatin and Eristostatin for Recognition of $\alpha_{\mathrm{IIb}} \beta_{3}$ and $\alpha_{\mathrm{v}} \beta_{3}$ Integrins," FEBS Letters, Vol. 391, No. 1-2, 1996, pp. 139-143. http://dx.doi.org/10.1016/0014-5793(96)00716-8

[19] M. Trikha, Y. A. De Clerck and F. S. Markland, "Contortrostatin, a Snake Venom Disintegrin, Inhibits $\beta 1$
Integrin-Mediated Human Metastatic Melanoma Cell Adhesion and Blocks Experimental Metastasis," Cancer Research, Vol. 54, No. 18, 1994, pp. 4993-4998.

[20] Q. Zhou, M.T. Nakada, P.C. Brooks, S.D. Swenson, M. R. Ritter, S. Argounova and C. Arnold, "Contortrostatin, a Homodimeric Disintegrin, Binds to Integrin $\alpha_{\mathrm{v}} \beta_{5}$," Biochemica Biophysica Research Communication, Vol. 267, No. 1, 2000, pp. 350-355. http://dx.doi.org/10.1006/bbrc.1999.1965

[21] F. S. Markland and Q. Zhou, "Snake Venom Disintegrin: An Effective Inhibitor of Breast Cancer Growth and Dissemination," American Chemical Society Symposia Series, Vol. 745, 2000, pp. 262-282.

http://dx.doi.org/10.1021/bk-2000-0745.ch018

[22] Q. Zhou, M. T. Nakada, C. Arnold and F. S. Markland, "Contortrostatin, a Dimeric Disintegrin from Agkistrodon contortrix contortrix, Inhibits Angiogenesis," Angiogenesis, Vol. 3, No. 3, 1999, pp. 259-269. http://dx.doi.org/10.1023/A:1009059210733

[23] Q. Zhou, M. Ritter and F. S. Markland, "Contortrostatin, a Snake Venom Protein, Which Is an Inhibitor of Breast Cancer Progression," Molecular Biology of the Cell, Vol. 7, No. S425a, 1996.

[24] Q. Zhou, R. P. Sherwin, C. Parrish, et al., "Contortrostatin, a Dimeric Disintegrin from Agkistrodon contortrix contortrix, Inhibits Breast Cancer Progression," Breast Cancer Research and Treatment, Vol. 61, No. 3, 2000, pp. 249-260. http://dx.doi.org/10.1023/A:1006457903545

[25] A. Georgoulis, S. Havaki, Y. Drosos, N. Goutas, D. Vlachodimitropoulos, V. Aleporou-Marinou, C. Kittas, E. Marinos and M. Kouloukoussa, "RGD Binding to Integrin AlphavBeta3 Affects Cell Motility and Adhesion in Primary Human Breast Cancer Cultures," Ultrastructural Pathology, Vol. 36, No. 6, 2012, pp. 387-399. http://dx.doi.org/10.3109/01913123.2012.681834

[26] F. S. Markland, "Snake Venoms and the Hemostatic System" Toxicon, Vol. 36, No. 12, 1998, pp. 1749-1800. http://dx.doi.org/10.1016/S0041-0101(98)00126-3

[27] S. Schmitmeier, F. S. Markland and T. C. Chen, "AntiInvasive Effect of Contortrostatin, a Snake Venom Disintegrin, and TNF-Alpha on Malignant Glioma Cells," Anticancer Research, Vol. 20, No. 6B, 2000, pp. 42274233.

[28] R. S. Karthikeyan, M. Karthigayan, Sri Balasubashi, S. Vijayalakshni and T. Balasubramanian, "Antitumor Effect of Snake Venom (Hydrophis spiralis) on Ehrlich Ascites Carcinoma Bearing Mice," International Journal of Cancer Research, Vol. 3, No. 4, 2007, pp. 167-173. http://dx.doi.org/10.3923/ijcr.2007.167.173

[29] L. Contois, A. Akalu and P. C. Brooks, "Integrins as 'Functional Hubs' in the Regulation of Pathological Angiogenesis," Seminars in Cancer Biology, Vol. 19, No. 5, 2009, pp. 318-328.

http://dx.doi.org/10.1016/j.semcancer.2009.05.002

[30] Mahabeleshwar, G. H. Feng, W. D. R. Phillips and T. V. Byzova, "Integrin Signaling Is Critical for Pathological Angiogenesis," Journal of Experimental Medicine, Vol. 203, No. 11, 2006, pp. 2495-2507. http://dx.doi.org/10.1084/jem.20060807 
[31] J. D. Hood and D. A. Cheresh, "Role of Integrins in Cell Invasion and Migration," National Review of Cancer, Vol. 2, No. 2, 2002, pp. 91-100. http://dx.doi.org/10.1038/nrc727

[32] J. Folkman, “Angiogenesis: An Organizing Principle for Drug Discovery?" National Review of Drug Discovery, Vol. 6, No. 4, 2007, pp. 273-286. http://dx.doi.org/10.1038/nrd2115

[33] J. A. Nemeth, M. T. Nakada, M. Trikha, Z. Lang, M. S. Gordon, G. C. Jayson, R. Corringham, U. Prabhakar, H. M. Davis and R. A. Beckman, "Alpha-v Integrins as Therapeutic Targets in Oncology," Cancer Investigation, Vol. 25, No. 7, 2007, pp. 632-646. http://dx.doi.org/10.1080/07357900701522638

[34] G. C. Tucker, "Integrins: Molecular Targets in Cancer Therapy," Current Oncology Reports, Vol. 8, No. 2, 2006, pp. 96-103. http://dx.doi.org/10.1007/s11912-006-0043-3

[35] R. Minea, C. Helchowski, B. Rubino, K. Brodmann, S. Swenson and F. Markland Jr., "Development of a Chimeric Recombinant Disintegrin as a Cost-Effective AntiCancer Agent with Promising Translational Potential," Toxicon, Vol. 59, No. 4, 2012, pp. 472-486. http://dx.doi.org/10.1016/j.toxicon.2011.02.020

[36] L. M. Ellis and D. A. Reardon, "Cancer: The Nuances of Therapy,” Nature, Vol. 458, No. 7236, 2009, pp. 290-292. http://dx.doi.org/10.1038/458290a

[37] E. Lin, Q. Wang, S. Swenson, H. Jadvar, S. Groshen, W. Ye, F. S. Markland and J. Pinski, "The Disintegrin Contortrostatin in Combination with Docetaxel Is a Potent Inhibitor of Prostate Cancer in Vitro and in Vivo," Prostate, Vol. 70, No. 12, 2010, pp. 1359-1370. http://dx.doi.org/10.1002/pros.21173

[38] S. Havaki, M. Kouloukoussa, K. Amawi, Y. Drosos, L. D. Arvanitis, N. Goutas, D. Vlachodimitropoulos, S. D. Vassilaros, E. Z. Katsantoni, I. Voloudakis-Baltatzis, V. Aleporou-Marinou, C. Kittas and E. Marinos, "Altered Expression Pattern of Integrin AlphavBeta3 Correlates with Actin Cytoskeleton in Primary Cultures of Human Breast Cancer," Cancer Cell International, Vol. 7, No. 2, 2007, pp. 16-28. http://dx.doi.org/10.1186\%2F1475-2867-7-16

[39] P. G. Sells, “Animal Experimentation in Snake Venom Research and in Vitro Alternatives," Toxicon, Vol. 42, No. 2, 2003, pp. 115-133. http://dx.doi.org/10.1016/S0041-0101(03)00125-9 